\title{
Determining the size of technological gap between local firms and foreign direct investment at regional level
}

\author{
Sylvie Kotikova \\ Department of Economics, Faculty of Economics, \\ Tecbnical University of Liberec, \\ Crech Republic \\ sylvie.kotikova@tul.cz. \\ Roman Vavrek* \\ Department of Informatics, Faculty of Economics, \\ Tecbnical University of Liberec, \\ Crech Republic \\ vavrek.roman@gmail.com
}

ORCID: 0000-0002-6047-9434

Abstract. The size of technology gap is one determinant of indirect spillover effects from FDI. Whether and to what extent FDI inflows generate positive spillovers affecting productivity growth of host country firms depends on several factors, including the degree of FP and the position of local and foreign businesses. The FDI index we created, follows the difference between the technology level of foreign companies and the regional business environment. The shift-share analysis is complemented by TOPSIS, which evaluated Czech regions individually between 2002 and 2017 on the basis of maximization and minimization data (individual components of RRTG). The aim of the paper is to determine the extent to which the presence of FDI is reflected in productivity of business environment. Regional evaluations via RRTG and TOPSIS significantly correlate. The differences in both versions are identified by comparing the mean values and the distribution functions of the results. The application of our approach to local regions is unique in identifying the size of technology gap at NUTS 3 levels. The advantage of this approach is its ease of modification. The studied set of regions can be indefinitely expanded and it is applicable to other territorial units and different time series.

Keywords: FDI, technological gap, TOPSIS technique, regional comparison.

JEL Classification: B23, R12, O18

\footnotetext{
${ }^{*}$ Corresponding author
} 


\section{INTRODUCTION}

Foreign direct investment (hereinafter also "FDI") and its determinants is a widely discussed topic within economic literature (Bobenic Hintosova, 2018). Countries attract FDI by offering incentives. Efforts to attract FDI can be quantified through the value of the incentives offered, but their impact on a host country's business environment is less quantifiable. Business environment is a set of political, legal, economic, technological, social and cultural factors that influence entrepreneurial activity, performance, competitiveness, and growth. They determine the attractiveness of a state or a region for foreign investors (Hlavacek \&Bal-Domanska, 2016; Prokop \& Karbowski, 2018).

Data collection complicates the evaluation of regional and subregional business environments, particularly when data are only nationally reported. Another problem in evaluating regional business environments is that incentives to attract FDI might not apply regionally. Laws that govern international trade might not apply to inter-regional trade (Camagni, 2009). Exchange rate differentials and shifting price and wage ratios might not have regional consequences, but inter-regional mobility in production factors (e.g., labour, capital) can pose regional threats. Moreover, FDI could generate conflicting regional impacts, and it is hard to quantify spillovers that lack clear ties to FDI (Kotikova, 2017).

Huggins' (2003) competitiveness index overcomes some difficulties in evaluating national and subnational business environments by including data that are nationally, regionally and locally comparable and by correlating macroeconomic outputs and the business environment. Benchmarking per capita gross domestic product facilitates the comparison of regional business environments in the UK.

Christopherson, Kitson, Michie (2008) examined productivity as an indicator of regional competitiveness, and Gardiner et al. (2004) analyzed regional labour efficiencies in Europe and found sluggish regional convergence among the European Union (EU)-15 countries. According to Koisova, Grmanova, Habanik (2018), competitiveness is also closely connected with innovative activities and innovations are becoming a driving force for business entities. Small and medium-sized enterprises (SMEs), in particular, are considered to be the key innovators. The persistence of regional productivity gaps across the EU clearly raises key issues for the structural fund allocation policy.

These indicators reflect the fact that quality of business environment affects whether foreign firms invest in a region. However, when firms from strong economies with high-quality business environments enter less developed economies, they bring pressure to improve the business environment there. Business environments and FDI inflows are reciprocal a high-quality business environment can localize FDI and FDI inflows shape the host's business environment. Quality of business environment houses the potential for FDI effects.

The aim of this paper is to determine the extent to which the presence of FDI is reflected in productivity of the business environment. Our results and conclusions would contribute to available economic research on technological gap between host and maternal economies in relation to FDI. Since the size of technological gap is mainly monitored at the economy level, the paper provides an innovative way of monitoring the technological gap at the level of regional business environment, identifying interregional disparities within a host economy.

The following chapter presents the main economic streams dealing with FDI, followed by the main part of the paper. How is it possible to evaluate the size of technological gap? First, the indicator of regional technological gap is calculated through shift-share analysis and then the Technique for Order of Preference by Similarity to Ideal Solution (TOPSIS) as a multiple-criteria decision-making method is used. The methodological approach is applied to a group of selected regions in Czech Republic. Conclusions concerning regional disparities in the presence of foreign companies and the size of technological gap are provided. 


\section{LITERATURE REVIEW}

The localization of businesses has been a topic of interest in the FDI literature since the early 20th century, with researchers studying how attracting FDI influences regional business environments. The following five theoretical approaches address this and related questions:

- Neoclassical and neoliberal theories, notably localization theory and new economic geography (Krugman, 2011; Krugman \& Fujita, 2014);

- Keynesian concepts, especially the Harrod-Domargrowth investment model and growth center theory (Hochstein, 2017);

- Structuralist approaches, particularly the theory of changes in global production (Sharma, 1984; Bogataj, Bogataj \& Drobne, 2019);

- Institutional approaches, such as the theory of production districts or of global production networks (Gambus \& Almeida, 2018);

- The theory of international trade, especially Vernon's (1966) theory of the production cycle.

Three agglomeration effects (concentration mechanisms) of localization emerged from Marshall's (1920) study of business performance:

- Geographical concentration supports the availability of inputs for both customers and suppliers;

- Knowledge transfer intensifies with geographical concentration;

- Sharing encourages specialization of labour. Enterprises can hire workers whose factor endowments meet their requirements and need not hire workers with merely tangential qualifications (Blazek, 2016).

These effects (mechanisms) explain how companies increase productivity by localizing into clusters. Although influences vary by sector, empirical surveys confirm the effect of the labour market overall (Baldwin, 2008).

Localization theories have been criticized for simplifying neoclassical assumptions (e.g. minimizing transport costs, maximizing profits) and for reducing social problems to spatial problems. The conflict between dynamic reality and unrealistic simplifications altered the focus of research in the 1970s. Later studies concentrated on development and lags (Blazek, Hampl \& Zizalova, 2008).

Nobel laureate Paul Krugman (Krugman \& Venables, 1995) cited three effects of global economic change: the market access effect, the cost-of-living effect and the displacement effect (i.e. imperfectly competitive firms locate production where competition is relatively low). Krugman's economic geography involves a neoclassical modelling of localization factors but replaces unrealistic neoclassical postulates about diminishing returns with the concepts of external savings and imperfect competition. Doing so permits modelling conditions under which economic activity spatially concentrates.

It is assumed that increasing returns of companies explain regional specialization, industry concentration and clustering of firms for international competitiveness. The concentration of companies and industries determines the multiplier effect when other foreign investors and domestic firms follow the initial FDI. Creating and maintaining competitive advantage related to the size and depth of cooperation among economic entities and the extent to which regional domestic firms can innovate and engage the global production chain (Krugman, 2011).

Krugman and Venables (1995) enumerated the geographic advantages of locations with favourable market access when transaction costs are high. If transport and commercial costs are relatively low, regional geographic advantages and market potential seldom motivate foreign investors to relocate production. In other words, economic integration during the pilot stages of FDI spurs regional differentiation. In subsequent stages, dispersion invites competition in the agglomeration region, and living costs increase. As wages rise, economic activity disperses to neighbouring regions. This cyclical 
causality, in which regions with agglomeration advantages confront wage-cost disparities in adjoining regions, naturally occurs in open economies.

The foregoing discussion explains why FDI deepens regional disparities and polarises regions. Investment in peripheral areas weakens agglomeration and strengthens dispersion of economic activity into peripheral regions (Simanova \& Tresl, 2011). One group of countries, Gulf Cooperation Council countries, are not using FDI as a strategy to capitalize on their economic power in the region (Abidi et al., 2018). The first to investigate secondary impacts of FDI on host economies, Finlay (1978) found that technology gaps between originating and host economies determine spill-over effects - the larger the gap, the greater is the effect - but he assumed that foreign investors are always from economies more advanced than the areas in which they invest. Based on a case study of Simonescu (2018), exports have a positive influence on FDI. It is also confirmed, that slowing down economy may become the stronger factor than integration for changing the direction of FDI outflows from the country (Kaminska, Babula, Bitzer, Geishecker \& Gorg, 2008; Barrios, Gorg \& Strobi, 2011; Cantwell, 2017; Cohen \& Levinthal, 1990; 2015) moderated the effect of technology gaps on spill-overs. They suggested that if the technology gap is excessive, domestic firms cannot transfer technology horizontally (i.e. the FDI imitation effect) or vertically. Enormous technology gaps produce a crowding-out effect when local firms cannot compete with foreign investors, whereas insufficiently large technology gaps provide no room for learning and technology transfer. Consequently, positive spill-overs likely occur around moderate technology gaps.

This is also confirmed by Falk (2015) who, on the basis of a sample of 38,000 companies from Central and Eastern Europe, found that the performance of local suppliers only benefited from the presence of foreign firms if the technological gap between these groups of companies was not too great.

Technology gaps are related to whether firms in host markets can acquire knowledge created by others and modify it for their needs (Szent-Ivanyi \& Vigvari, 2012; Narula \& Marin, 2005). Their absorption capacity also determines indirect effects from FDI (Narula, 2017) and expresses a region's technological standing, infrastructure, cultural and social capital, financial institutions and institutional effects on the business environment (Xu, 2000). Human capital is crucial because FDI inflows create a potential for technological transfer to the host country and because human capital in the host labour market determines the number and structure of foreign companies attracted to the region and the extent of home-grown businesses (Kotikova, 2017). It follows, then, that the productivity of labour and its alteration over time indicate the quality of business environments and firms' absorption capacities.

This study examines technology gap and business environments in six regions of the Czech Republic between 2002 and 2017. Common features are the neighbourhood and border nations of the regions.

\section{METHODOLOGY}

We determine the development of technology gaps using shift-share analysis. Shift-share analysis frequently appears in the literature concerning employment dynamics, labour productivity and added value (Zdenek \& Strelecek, 2012). To determine the dynamics of an observed phenomenon, the analysis employs a three-effect decomposition in which the third component captures the interplay between the other two components. This approach is suitable for identifying and researching regional disparities. Here, we decompose regional technology levels into a technology effect, an effect of employment and the combination of both effects.

Maudos et al. (2008) explained changes in labour productivity in 47 sectors of the EU and the U.S.by decomposing intra-sectoral, static sectoral and dynamic sectoral effects. The latter two constitute a structural change effect. Esteban's (2000) shift-share analysis evaluated the multi-sector structure of labour productivity with regional differences at the national level in the EU. Simanova, Tresl (2011) observed the 
technology gap in the Czech Republic by decomposing shift-share analysis into a technological effect, sectoral effect and a combination of these effects. They compared their selected benchmark to productivity in four sectors. Zdenek and Strelecek (2012) used the method to assess regional and sectoral labour productivity and average wages and employment from 2004 to 2008 when accelerated economic growth was expected. As its main advantage, shift-share analysis can be applied to any hierarchy of regions and choice of assessed components. Formula (1) indicates its decomposition. It is the sum of three components of the basic approach to determining the relative regional technology gaps (RRTG) attributable to a foreign presence (FP), represented as follows:

$R R T G_{n}=\frac{\sum_{i=1}^{r}\left(A P_{L i}^{F D I}-A A P_{B}^{r e g}\right) \cdot F P_{B}^{r e g}}{A A P_{B}^{r e g}}+\frac{\sum_{i=1}^{r}\left(F P_{i}^{F D I}-F P_{B}^{r e g}\right) \cdot A A P_{B}^{r e g}}{A A P_{B}^{r e g}}+\frac{\sum_{i=1}^{r}\left(A P_{L i}^{F D I}-A A P_{B}^{r e g}\right) \cdot\left(F P_{i}^{F D I}-F P_{B}^{r e g}\right)}{A A P_{B}^{r e g}}$

where $A P_{L i}^{F D I}$ is the productivity of foreign companies in a host country (Organisation for Economic Co-operation and Development (OECD), 2019) by country of origin in year $\mathrm{n} ; A A P_{B}^{r e g}$ is the productivity of a benchmark, here the arithmetic mean productivity in the six Czech regions in year $\mathrm{n} ; F P_{i}^{F D I}$ is the share of employees of foreign companies by country of origin and the total employed in the region in year $\mathrm{n}$ and $F P_{B}^{r e g}$ is the benchmark for the share of employees of foreign firms in the six regions in year $\mathrm{n}$, calculated as an arithmetic mean of the share of employees in the regions.

The RRTG indicator observes the difference between the productivity (i.e. technology level) of 230 FDI and the regional business environment in the six Czech regions from 2002 to 2017. Observing the progress of this indicator facilitates the prediction of productivity growth in regions with an extensive FP and its comparison to regions with lesser FDI. RRTG indicates regions that lag the technology level of multinational corporations (MNCs) and identifies where lags originate. The width of the lag denotes the extent of the FP; its depth indicates differences in labour productivity.

The first component "productivity" shows whether regions trail behind the productivity of foreign firms. It is a relative indicator in which the denominator average regional productivity is our benchmark. Thus, it has greater reporting power when comparing sets of regions. If benchmarked average regional productivity exhibits disproportional growth, the productivity component of RRTG should decline over time. That decline indicates diminishing growth potential but a high capacity to absorb knowledge and skills in the surveyed regions.

It would be ideal for sustained growth in regional productivity and for growth in the productivity component of RRTG if new MNCs continually entered regions with rising labour productivity and created jobs. This would sustain an increase in the indicator even if regions perfectly absorbed foreign investors' technology.

The second component of RRTG "employment" is the difference in technology levels generated by differing magnitudes of FP. The component shows the width of the regional technology lag and the possibility of reducing it by attracting FDI (Formula 1). Growth in the employment component indicates that foreign firms in the region create many jobs, accelerating the transfer of technology and knowledge. When interpreting RRTG results, however, remember first that component values may decline notwithstanding is proportional growth in benchmarked regional productivity. That occurrence may signal many circumstances, e.g. the region lags the benchmarked share of workers in foreign companies or the region encompasses countries with low productivity. Second, be aware that values for the employment component may be negative, notwithstanding a higher share of employees than the regional benchmark, or values may be below the productivity component. In this case, a region may have somewhat higher productivity growth and greater FDI use. 
The third component of RRTG is the combination of productivity and employment effects; it summarises the degree of their interdependence (Kotikova \& Cuhlova, 2016).

For the resulting indicator values, then:

- The more a region achieves, the greater is the potential for indirect spill-over effects. The higher the value of the RRTG indicator versus other regions, the higher is the potential for technological growth. The magnitude of the value of the RRTG is given by the quantity of FDI in the region, the region's technology level compared to labour productivity in countries where FDI originates and foreign firms' shares in the region's employment.

- The higher the productivity component of RRTG and the higher the positive difference between values in the productivity and employment components, the deeper is a region's technology lag compared to the benchmark.

- Economic development progresses ideally when the first component of Formula (1) declines as average regional productivity grows and the second component rises or stagnates around 0 when FDI comprises an increasing share of employment. This situation signals escalating numbers of new jobs in the region and the ability to absorb imported knowledge and skills. This should be attributable to increased labour productivity, e.g. in growth of employment, wages and the number of domestic (and foreign) firms that are subcontractors of incoming foreign firms.

- If the employment component of RRTG attains high positive values, the region transfers technology and productivity more speedily.

The described approach must be taken in space and time with certain assumptions. Some are restrictive and reduce the indicator's ability to provide information - e.g. abstraction from the interconnectedness of the regions-but they cannot be fully included in the model As well as does not consider the absolute contribution of foreign companies to the region. Other limits of current research which should be considered are:

- It does not take into account the interconnectedness of the regions (e.g. transfer of acquired technical knowledge gained from FDI between regions).

- It does not take into account the interaction between companies in the region or between regions. This would lead to the need for adjustment the annual productivity levels for the individual countries from which the investment comes into the examined region.

- It does not consider the absolute rate of contribution of foreign companies to the region.

- It does not consider outsourcing in the area of HR. Only employees reported in the annual reports enter the FP. It does not take into account the delivery of agency employees.

\subsection{Technique for Order of Preference by Similarity to Ideal Solution as a multiple- criteria decision-making method}

The TOPSIS technique (Technique for Order of Preference by Similarity to Ideal Solution) tries to choose solutions that are simultaneously close to the ideal solution and far from the nadir solution (Zavadskas, et al., 2016). It is one of the MCDM methods that have been effectively used for solving many different selection/ranking problems Opricovic and Tzeng (2002) described positive ideal solution (PIS) as an alternative that maximises revenue criteria while minimising cost criteria. Negative ideal solution (NIS) is the opposite, maximising costs and minimising revenues.

According to Shih, Shyur, Lee (2006), this technique enables decision-makers to analyse problems, compare alternatives and ordinate solutions per selected criteria. TOPSIS is the most direct method of multiple-criteria decision-making. Pavic and Novoselac (2013) argued that it is the preferred decision- 
making tool when data are incomplete and that it permits any range of data (Kandakoglu, Celik \& Akgun, 2008; Shih, Shyur \& Lee, 2006).

The first step in TOPSIS is to construct a matrix that ranks alternatives by pre-identified criteria (characteristics) (Milani, Shanian \& El-Lahham, 2008):

$$
D=\left(\begin{array}{ccccc} 
& X_{1} & X_{2} \ldots & X_{j} \ldots & X_{n} \\
A_{1} & x_{11} & x_{12} \ldots & x_{1 j} \ldots & x_{1 n} \\
A_{2} & x_{21} & x_{22} \ldots & x_{2 j} \ldots & x_{2 n} \\
: & : & : & : & : \\
A_{i} & x_{i 1} & x_{i 2} \ldots & x_{i j} \ldots & x_{i n} \\
: & : & : & : & : \\
A_{m} & x_{m 1} & x_{m 2} \ldots & x_{m j} \ldots & x_{m n}
\end{array}\right)
$$

where $A_{i}$ is $\mathrm{i}$-th variant and $x_{i j}$ is the value of $\mathrm{j}$-th criterion reached by $\mathrm{i}$-tj variant.

The next step is to normalise this matrix using the following relationship:

$$
r_{i j}=x_{i j} / \sqrt{\sum_{j=1}^{j} x_{i j}^{2}}
$$

where $r_{i j}$ is the normalised value of $\mathrm{j}$-th criterion reached by $\mathrm{i}$-t $\mathrm{j}$ variant and $\mathrm{x} \_\mathrm{ij}$ is the value of the $\mathrm{j}$ th criterion reached by $\mathrm{i}$-tj variant.

The matrix is multiplied by weights of the relevant criteria through that relationship (Peng et al., 2012) as follows:

$$
v_{i j}=w_{i j} \cdot r_{i j}
$$

where $v_{i j}$ is the weighted normalised value and w_ijis the criterion's weight. The normalised matrix contains values from which PIS and NIS are identified. These variants can be real or hypothetical alternatives of the best or worst results achieved. Identification of PIS and NIS can be represented as follows:

$$
H_{j}=\max \left(w_{i j}\right), D_{j}=\min \left(w_{i j}\right)
$$

where $H_{j}$ is the PIS and $D_{j}$ the NIS.

The distance of the obtained PIS and NIS can be calculated according to

$$
d_{i}^{+}=\left[\sum_{j=1}^{k}\left(w_{i j}-H_{j}\right)^{2}\right]^{1 / 2}, d_{i}^{-}=\left[\sum_{j=1}^{k}\left(w_{i j}-D_{j}\right)^{2}\right]^{1 / 2}
$$

where $d_{i}^{+}$is the distance to PIS and $d_{i}^{-}$is the distance to NIS.

The desired minimum distance from PIS is $(\mathrm{d}+)$ and the desired maximum distance from NIS is $(d-)$. The relative distance from PIS is the criterion for ranking alternatives. The relationship below considers the two distances identified from the previous step.

Milani, Shanian, El-Lahham (2008) and Wu, Hsieh, Chang (2013) disregarded the final step in TOPSIS, which includes ranking based on relative proximity to the PIS alternative. The best-rated alternative (subject) is the one with the highest value. This procedure is also used by in our own research too (Vavrek, Chovancova, 2019; Vavrek, 2017 or Vavrek, Adamisin, Kotulic, 2015).

As input criteria for the TOPSIS technique, we use the three components of the RRTG. For the purpose of this manuscript, indicators are equal, i.e. each indicator has the same weight. 


\subsection{Other statistical methods used}

We evaluated regions in the Czech Republic separately using RRTG and TOPSIS and tested their relationships via the Kendall sequence correlation coefficient,

$$
r_{K}=\frac{n_{c}-n_{d}}{n(n-1) / 2}
$$

where $n$ is the number of observed pairs of variables, $n_{c}$ is the number of discordant pairs and $n_{d}$ is the number of concordant pairs.

We normalised the resulting structure and compared the differences. The Kolmogorov-Smirnov test compares the distribution function as follows:

$$
\begin{aligned}
D_{n_{1}, n_{2}}= & \sup \left|F_{1, n_{1}}(x)-F_{2, n_{2}}(x)\right| \\
& -\infty<x<\infty
\end{aligned}
$$

where $F_{1, n_{1}}(x)$ is the empirical distribution function of the first selection and $F_{2, n_{2}}(x)$ is the empirical distribution function of the second selection.

The mean value match (median) is tested by the Mann-Whitney test as follows:

$$
U^{\prime}=n_{y} n_{x} \frac{n_{y}\left(n_{y}+1\right)}{2}-R_{y}, U=n_{y} n_{x}-U^{\prime}
$$

where $n_{x}$ is the number of $\mathrm{x}$-th sample observations, $\mathrm{n} \_\mathrm{yis}$ the number of $\mathrm{y}$-th sample observations, R_yis the sum of the $y$-th sample order, and $U, U^{\prime}$ is the test criterion.

Each of above-mentioned belongs to nonparametric methods which have many pros and also cons. These methods are not dependent on the shape of the data distribution (normal distribution was not confirmed for any data used), data friendly and can be applicable to small research samples. Their main disadvantage is that the results powerless than the results of parametric methods.

We used MS Excel, Statistica 13.4 and Statgraphics XVIII for the analyses.

\section{EMPIRICAL RESULTS AND DISCUSSION}

This section explains the calculation and evaluation of RRTG development in individual regions. We evaluate the overall RRTG for each region and identify the possible causes and contexts for given RRTG values. Table 1 shows countries of origin for investors in each region, with Germany and the UK as the most represented.

Table 1 scans investors' countries of origin but makes no statement about the degree of FP in each country, which is embodied into Formula (1) using the weight $F P_{i}^{F D I}$.

The table 2 shows, with reference to benchmark values, which regions are below average and above average. In this context, the Carlsbad region, which has never been close to benchmark values, has a critical position. Although the Carlsbad region is located at the attractive border with Germany, the Carlsbad region does not use potential for growth. The region is struggling with long-term disproportion in the labour market. Educational supply does not match labour market demand. This problem is multiplicities by the low willingness of workers to commute to other regions (Czech Statistical Office, 2018). In contrast, the Pilsen Region takes full advantage of its geographical location, connects to the business environment of the neighbouring well-developed Bavaria region, and has above-average productivity. This result shows that economically and socially troubled regions must offer well-crafted investment incentives. 
Table 1

Overview of countries of origin of FDI

\begin{tabular}{|c|c|c|c|c|c|c|}
\hline & Pilsen & Carlsbad & Usti n. L. & Liberec & H. Kralove & Pardubice \\
\hline Germany & $\mathrm{X}$ & $\mathrm{X}$ & $\mathrm{X}$ & $\mathrm{X}$ & $\mathrm{X}$ & $\mathrm{X}$ \\
\hline France & $\mathrm{X}$ & & $\mathrm{X}$ & $\mathrm{X}$ & $\mathrm{X}$ & $\mathrm{X}$ \\
\hline Belgium & $\mathrm{X}$ & & & $\mathrm{X}$ & $\mathrm{X}$ & \\
\hline United Kingdom & $\mathrm{X}$ & $\mathrm{X}$ & $\mathrm{X}$ & $\mathrm{X}$ & $\mathrm{X}$ & $\mathrm{X}$ \\
\hline Switzerland & $\mathrm{X}$ & $\mathrm{X}$ & $\mathrm{X}$ & $\mathrm{X}$ & & $\mathrm{X}$ \\
\hline Spain & $\mathrm{X}$ & & $\mathrm{X}$ & $\mathrm{X}$ & & $\mathrm{X}$ \\
\hline Austria & $\mathrm{X}$ & & $\mathrm{X}$ & & $\mathrm{X}$ & \\
\hline Italy & $\mathrm{X}$ & & $\mathrm{X}$ & & & $\mathrm{X}$ \\
\hline Nederland & & $\mathrm{X}$ & $\mathrm{X}$ & & $\mathrm{X}$ & $\mathrm{X}$ \\
\hline Sweden & & $\mathrm{X}$ & $\mathrm{X}$ & & & \\
\hline Norway & & & $\mathrm{X}$ & & & \\
\hline Luxemburg & & & $\mathrm{X}$ & & $\mathrm{X}$ & \\
\hline Denmark & & & & $\mathrm{X}$ & & $\mathrm{X}$ \\
\hline India & & & & & & $\mathrm{X}$ \\
\hline Israel & & & $\mathrm{X}$ & & & \\
\hline Mexico & & & $\mathrm{X}$ & & & \\
\hline Japan & $\mathrm{X}$ & $\mathrm{X}$ & $\mathrm{X}$ & $\mathrm{X}$ & & $\mathrm{X}$ \\
\hline USA & $\mathrm{X}$ & & $\mathrm{X}$ & $\mathrm{X}$ & $\mathrm{X}$ & \\
\hline China & & & $\mathrm{X}$ & & & \\
\hline Total number & 10 & 6 & 16 & 9 & 8 & 10 \\
\hline
\end{tabular}

Source: Authors' calculations

Table 2

Labour productivity in surveyed regions

\begin{tabular}{|l|c|c|c|c|c|c|c|c|c|c|}
\hline Regions & $\mathbf{2 0 0 2}$ & $\mathbf{2 0 0 3}$ & $\mathbf{2 0 0 4}$ & $\mathbf{2 0 0 6}$ & $\mathbf{2 0 0 8}$ & $\mathbf{2 0 1 0}$ & $\mathbf{2 0 1 2}$ & $\mathbf{2 0 1 4}$ & $\mathbf{2 0 1 6}$ & $\mathbf{2 0 1 7}$ \\
\hline Pilsen (PL) & 14.72 & $\mathbf{1 6 . 1 3}$ & 17.56 & 19.62 & 20.15 & 20.75 & 21.00 & 24.24 & 26.466 & 27.452 \\
\hline Carlsbad (KV) & 13.28 & 13.57 & 14.50 & 15.5 & 16.76 & 17.42 & 17.88 & 18.25 & 19.136 & 19.245 \\
\hline Usti na Labem (UL) & 14.39 & 15.71 & 16.73 & 19.04 & 20.47 & 20.99 & 21.88 & 21.81 & 22.522 & 22.682 \\
\hline Liberec (LB) & 14.36 & 14.17 & 14.84 & 17.88 & 19.18 & 19.42 & 21.50 & 21.75 & 23.162 & 25.14 \\
\hline Hradec Kralove (HK) & 14.21 & 15.00 & 16.97 & 18.10 & 20.57 & 20.96 & 21.02 & 23.86 & 26.001 & 27.033 \\
\hline Pardubice (PA) & 14.84 & 15.56 & 16.46 & 18.82 & 20.53 & 20.66 & 20.50 & 20.57 & 22.497 & 24.363 \\
\hline Benchmark (AAP $\mathbf{B})$ & $\mathbf{1 4 . 3 0}$ & $\mathbf{1 5 . 0 2}$ & $\mathbf{1 6 . 1 8}$ & $\mathbf{1 8 . 1 6}$ & $\mathbf{1 9 . 6 1}$ & $\mathbf{2 0 . 0 3}$ & $\mathbf{2 0 . 6 3}$ & $\mathbf{2 1 . 7 5}$ & $\mathbf{2 3 . 3 0}$ & $\mathbf{2 4 . 3 2}$ \\
\hline
\end{tabular}

Source: Authors' calculations

To illustrate regional technology gaps, it is best to compare RRTG across all regions. Figures 1-4 track RRTG and compare it for all six Czech regions. They also compare the three components of RRTG for all the regions sampled. The amount of RRTG is determined by the number of newly arrived and stilloperating MNCs in the region. The potential for economic and technological growth is higher if incentives have relatively attracted more FDI, job creation is greater (i.e. the region has a high FP) and FDI enters from technologically advanced economies.

The greatest technology gap appears throughout the Pilsen region (Figure 1). The difference in the RRTG ratio between Pilsen and other regions, except Usti nad Labem, deepens. Usti nad Labem was the second and final region wherein RRTG increased during the period. Its RRTG falls sharply only in the last reference year. This finding is explained by a decline in FP following revised employment practices. In this 
case, workers were employees of agencies, not of the firms where they worked, and they did not appear in FDI annual reports. A similar situation appears in the Hradec Kralove region.

The lowest values appear between 2007 and 2010 during the financial crisis and Eurozone debt crisis. The development of RRTG shows interesting facts. It clearly indicates the leader, excellent region (PL) and outsider in the group $(\mathrm{KV})$. The remaining regions, resp. standard regions, converge in value over time and within them, regional disparities are decreasing. Standard regions copy their development. This is illustrated, for example, by a fall in the values of Hradec Kralove Region in 2012, followed by Usti nad Labem region in 2014 and Liberec Region in 2015 to achieve a similar result in the final period. In 2016 and 2017 , the development of the curves is quite identical and gets closer in value.

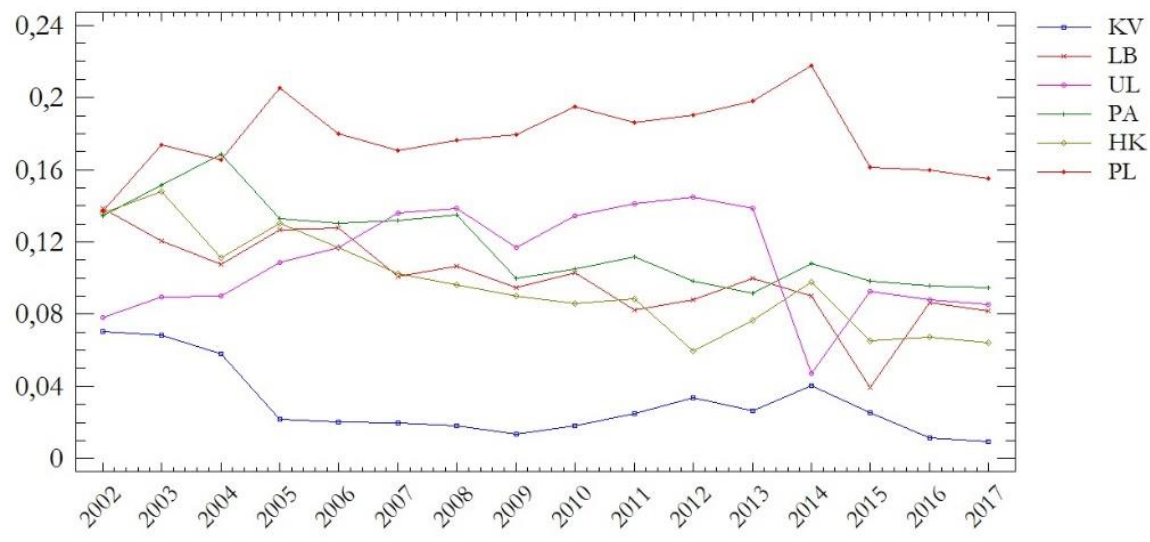

Figure 1. Development of RRTG in all regions from 2002 to 2017

Source: Authors' calculations

Above-average growth in labour productivity appears in regions in which RRTG grew. Regions with low or declining RRTG exhibit below-average growth in labour productivity (excluding Hradec Kralove). The surveyed regions exploited the emerging technology gap for economic growth. Regions unable or unwilling to attract foreign investors from advanced economies need lessly forfeited prospects for growth through technological transfers.

Hradec Kralove exhibits a deepening, nearly uninterrupted decline in RRTG values over the period not withstanding growth in early 2003 and late 2014. This finding indicates that the region could realize growth potential through foreign technology transfer. Therefore, it is surprising that labour productivity there grew most dynamically of all the regions during the sampled period (Table 2).

Hradec Kralove has the potential for self-reliant growth owing to its economic position in the Czech Republic and a wide representation of foreign companies. Thus, the region did not have to be in the centre of public support both from the representation of the region itself and from the representation of the state. A small interest in growth potential using the transfer of technological knowledge can also be seen by foreign firms that have received investment incentives alongside the development of the RRTG and of the proportion of employees of foreign firms with investment incentives in the total number of employees of Hradec Kralove. The Hradec Kralove region never exceeded 4\%. 


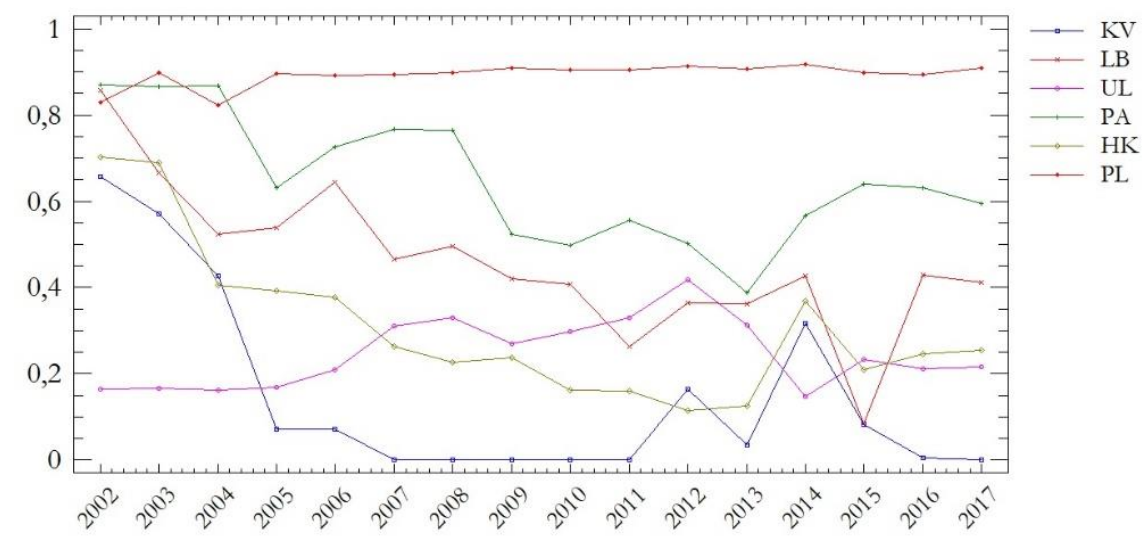

Figure 2. Development of TOPSIS in all regions from 2002 to 2017

Source: Authors' calculations

Excluding 2002 and 2004, Pilsen was the leading region under the TOPSIS technique, reflecting the trend in RRTG. Because Pilsen fell short of the maximum score in one year, at the least one region surpassed it in at the least one component of RRTG. The Pardubice region exhibits the lowest values for all three components in 2007 and 2008.

Table 3

Comparison of RRTG and TOPSIS Results

\begin{tabular}{|l|c|c|c|}
\hline & LC (RRTG - MCDM) & MEDIAN $\boldsymbol{D}$ & DF $\dagger$ \\
\hline Pilsen (PL) & $0,3833^{*}$ & $\mathrm{~S}$ & $\mathrm{~S}$ \\
\hline Carlsbad (KV) & $0,7394^{* *}$ & $\mathrm{D}$ & $\mathrm{D}$ \\
\hline Usti na Labem (UL) & $0,7500^{* *}$ & $\mathrm{D}$ & $\mathrm{S}$ \\
\hline Liberec (LB) & $0,7000^{* *}$ & $\mathrm{D}$ & $\mathrm{D}$ \\
\hline Hradec Kralove (HK) & $0,6500^{* *}$ & $\mathrm{D}$ & $\mathrm{D}$ \\
\hline Pardubice (PA) & $0,5833^{* *}$ & & \\
\hline
\end{tabular}

LC - linear correlation † comparison based on normalised data

Source: Authors' calculations

Regional evaluations by RRTG and TOPSIS linearly correlated (Table 3). The correlation is statistically significant for each region. A comparison of median and distribution functions, however, highlights statistically significant differences apart from Pilsen and Liberec. Based on above-mentioned results we can say that there is a difference between evaluation based on RRTG and TOPSIS method.

In the RRTG decomposition, productivity declines in all the regions (Figure 3). This is attributable to the construction of Formula 1. Because the productivity component grew more dynamically than the productivity of foreign companies, it had to have a declining slope. However, this development shows that this region can exploit technology gaps for economic growth. 


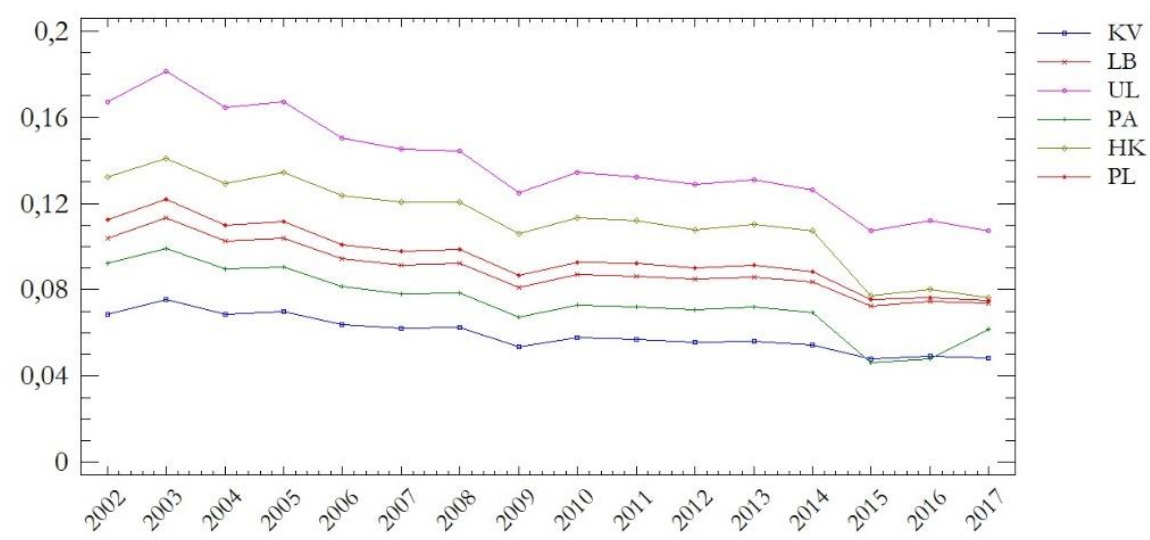

Figure 3. Development of the RRTG productivity component from 2002 to 2017 Source: Authors' calculations

Different situations influenced the curves in surveyed regions. For example, results for Usti nad Labem are attributable to its high share of employees of foreign companies. Hradec Kralove shows aboveaverage values because FDI originated in countries with high labour productivity (low number of countries of origin of investors; among them, the dominant highly above-average Luxembourg).

Low values for the Carlsbad region are attribute which can influence foreign investors' negligible interest in creating jobs there. Carlsbad has the lowest share of FDI in total employment, and its foreign investment originates in countries with productivity below that in developed economies. Variations in the employment component of RRTG for individual regions reflects the shape of each region's RRTG curves (Figure 4). A significant decline in the Usti nad Labem region in 2014 and a year later in the Liberec region was due to the massive employment of agency workers from third countries. These employees are not reported in the Company's annual reports. They are not expatriates or local (Czech) workers. These are third-country migrants who are employed by external agencies with whom FDI cooperates on the basis of outsourcing contracts.

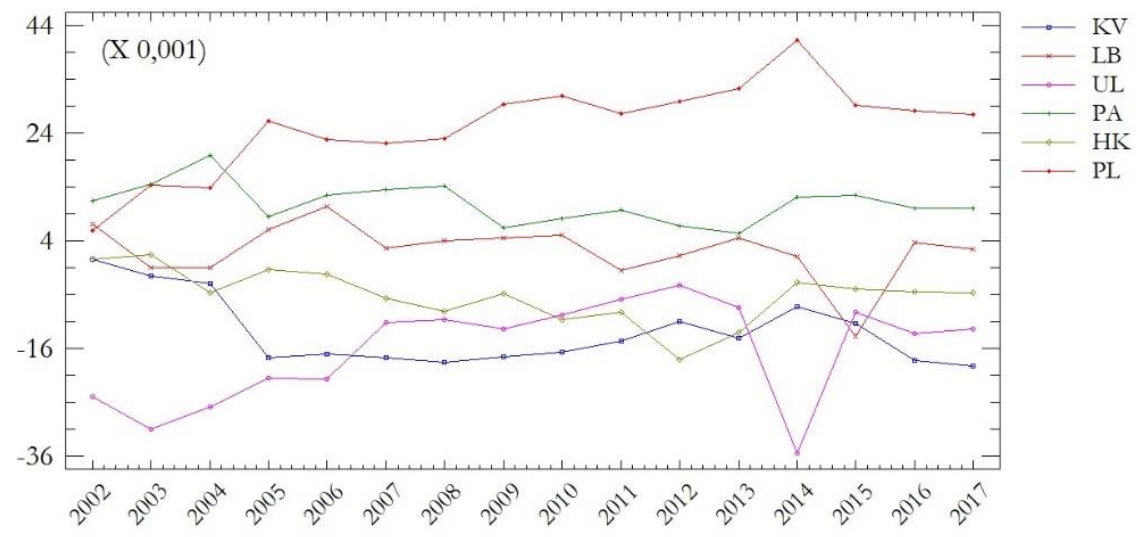

Figure 4. Development of the RRTG employment component in the examined regions from 2002 to 2017 Source: Authors' calculations

The dominance of Pilsen is clear; it attracted companies from developed economies that were interested in creating jobs. Carlsbad attracted few foreign companies and claimed a small share of the region's employment. Usti nad Labem presents an interesting situation. Although a rising RRTG curve 
enhanced the region's productivity, the employment component is among the lowest because Usti nad Labem attracted firms from more countries than any other region examined. Thus, technology transfer proceeded through a significantly broader set of nationalities. The depth of employment in Pilsen reflects a small proliferation of companies and countries. In other words, RRTG there is driven by exploiting the technology gap, and RRTG growth in Usti nad Labem is driven by the extensive use of the technology gap by foreign firms. The combination of both the effects shaped the RRTG curve and its employment component. The curves shifted under the influence of the productivity component (Figure 5).

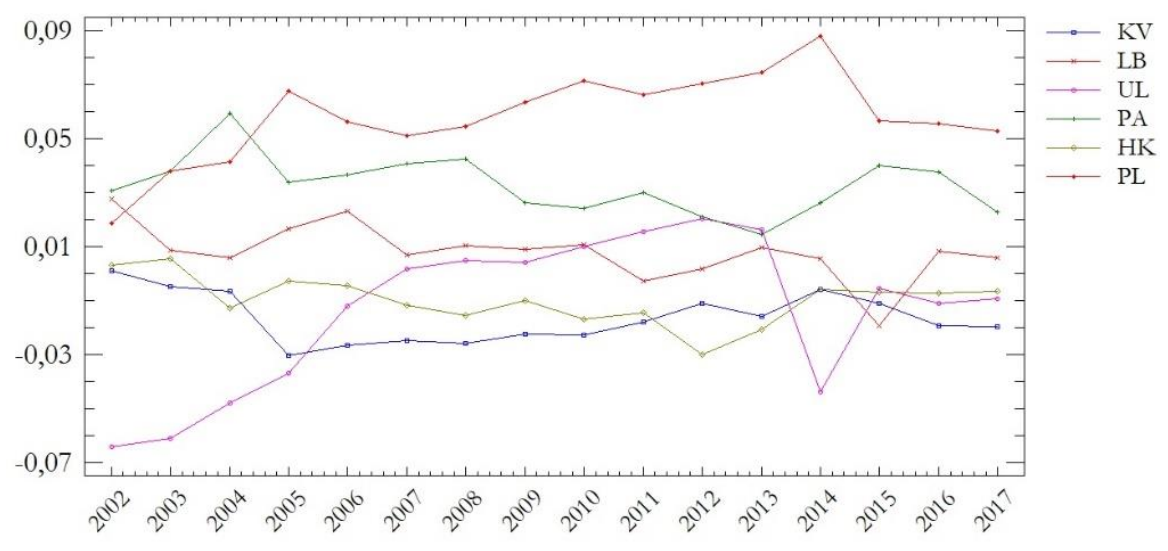

Figure 5. Combination of Both RRTG Effects in Examined Regions from 2002 to 2017

Source: Authors' calculations

Figure 5 also shows the dominance of Pilsen and the descent in Carlsbad. Carlsbad exhibits significantly lower and Pilsen significantly higher RRTG values than other surveyed regions. Economic development might differ in these geographically proximate regions because Pilsen is a centuries-old commercial locale whereas Carlsbad is a newly created autonomous region. The productivity and employment components contributed to high RRTG values in the Pilsen region but with differing dynamics. The former declines slightly and the latter ascends over time. The decline in productivity is attributable to labour productivity that surpasses the average for foreign firms. Growth in the employment component is attributable to the highest share of employment by foreign companies among the six regions. Growth in RRTG was attributable to an extensive cross-border interest in the region, its high FP and localization of interest in the region.

These findings correspond to the conclusions of Sanchez-Sellero et al. (2014) who, in the case of the Spanish economy, verified the thesis that technological advances are taking place in areas with a high foreign presence. The Carlsbad region is, however, the region with the lowest level of foreign presence and at the same time the region with the lowest labour productivity and the worst position in terms of technological gap. Government policy should, therefore, focus on attracting FDI into this area with an effort to improve the position of this peripheral region.

In general, the calculations made are beneficial to economic policy makers in terms of not only the technology transfer (from which countries of origin and where exactly FDI is heading), but mainly to determine the size of the technological gap at regional level. The calculations made provide answers to what extent regional business environments deal with technology transfer and foreign presence on their territory. Indeed, it is essential to monitor the size of the technological gap just at the lowest possible regional level, where the impact of foreign capital inflow is most significant. Policymakers then gain a more comprehensive and detailed picture of the status and development of regional disparities. 


\section{CONCLUSION}

This study addressed spill-overs from FDI by creating an indicator of relative regional technology gap using shift-share analysis. Through this method, the set was a relative regional technology gap indicator. The advantage of the constructed indicator is its ease of application and applicability to various national economies for the detection of interregional differences in the influence of FDI on the local business environment, as demonstrated in the case of the Czech Republic. The results obtained gain objectivity by applying the TOPSIS technique for multi-criteria evaluation of variants. On the basis of the results of individual analyses, we identified technology gaps for six regions in the Czech Republic. Evaluations using both the methods followed a linear relationship that allows mutual prediction of results. Individual differences were confirmed apart from the Pilsen region, where differences are attributable to the method used. These are shown when comparing the characteristics of position and shape. The result is a difference in the distribution function of the results obtained. The research provides for economic policymakers recommendations on which regions should focus on investment support for foreign investment attraction, as well as which regions are able to benefit from, and to what extent, the presence of FDI in their business environment.

The limitation of the RRTG indicator is, it does not take into account the interconnectedness of the regions (e.g. transfer of acquired technological knowledge gained from FDI between regions) and the RRTG does not consider the absolute rate of contribution of foreign companies to the region. Therefore, it is appropriate to monitor or construct the 'indicator of potential saturation' of the regional market and its capacities. The values of this indicator could then be a certain limitation on the use of the RRTG indicator.

In future will also be a suitable focus not only on the regional perspective but also on the crosssectoral perspective. In order to determine in more detail what and in which sectors the technology transfer is heading. As a result, it would be possible to provide more detailed information to economic policymakers, not only on regional technological transfer but also on cross-industry.

\section{ACKNOWLEDGEMENT}

This paper is supported by grant OP VVV no. CZ.02.2.69/0.0/0.0/16_027/0008493 and SGS no. 21295.

\section{REFERENCES}

Abidi, O., Antoun, R., Habibniya, H., \& Dzenopoljac, V. (2018). Firm-specific determinants of FDI from GCC to MENA countries. Journal of International Studies, 11(4), 9-21.

Baldwin, J. R., Beckstead, D., Brown, W. M. \& Rigby, D. L. (2008). Agglomeration and the geography of localization economies in Canada. Regional Studies, (42), 117-132.

Barrios, S., Gorg, H. \& Strobi, E. (2011). Spillovers through backward linkages from multinationals: Measurement matters!. European Economic Review, 55(6), 862-875.

Bitzer, J., Geishecker, I. \& Gorg, H. (2008). Productivity spillovers through vertical linkages: Evidence from 17 OECD countries. Economics Letters, $99(2), 328-331$.

Blazek, J. (2016). Towards a typology of repositioning strategies of GVC/GPN suppliers: the case of functional upgrading and downgrading. Journal of Economic Geography, 16(4), 849-869.

Blazek, J., Hampl, M. \& Zizalova, P. (2008). Factors - mechanisms - processes in regional development: An application of a critical realism methodology. Ekonomicky casopis, 56(7), 696-711.

Bobenic Hintosova, A., Bruothova, M., Kubikova, Z. \& Rucinsky, R. (2018). Determinants of foreign direct investment inflows: A case of the Visegrad countries. Journal of International Studies, 11(2), 222-235. 
Bogataj, D., Bogataj, M. \& Drobne, S. (2019). Interactions between flows of human resources in fluctional regions and flows of investors in dynamic processes of global supply chains. International Journal of Production Economics, 209, 215-225.

Camagni, R. (2009). Territorial Impact Assessment for European regions: A methodological proposal and an application to EU transport policy. Evaluation and Program Planning, 32(4), 342-350.

Cantwell, J. (2017). Innovation and international business. Industry and Innovation, 24(1), 41-60.

Christopherson, S., Kitson, M. \& Michie, I. (2008). Innovation, networks and knowledge exchange. Cambridge Journal of Regions Economy and Society, 1(2), 165-173.

Cohen, W. M. \& Levinthal, D.A. (1990). Absorptive capacity: a new perspective on learning and innovation. Administrative Science Quarterly, 1990(35), 128-152.

Cohen, W. M. \& Levinthal, D.A. (2015). Innovation and Learning: The Two Faces Of R\&D. Economic Journal, 125(583), 546-573.

Czech Statistical Office (2018) Statistical Yerbooks.

Falk, M. (2015). The relationship between FDI through backward linkages and technological innovations of local firms: evidence for emerging economies. Eastern European Economics, 53(5), 424-438.

Gambus, I. \& Almeida, F. (2018). Three Decades after James Street's. "The Institutionalist Theory of Economic Development": What Does Institutional Approach to Economic Development Mean Today?. Journal of Economic Issues, 52(2), 455-463.

Gardiner, B. et al. (2004). Competitiveness, productivity and economic growth across the European regions. Regional Studies, 38(9), 991-999.

Hlavacek, P. \& Bal-Domanska, B. (2016). Impact of foreign direct investment on economic growth in Central and Eastern European Countries. Inqinerine Ekonomika-Engineering Economics, 27(3). 294-303.

Hochstein, A. (2017). The Harrod-Domar model in a Keynesian framework. International Advances in Economic Research, 23, 349-350.

Huggins, R. (2003). Creating a UK competitiveness index: Regional and local bechmarking. Regional Studies, $37(8), 89$ $-96$.

Kaminska, T. \& Babula, E. (2014). The Hicksian Effects and FDI after Poland's accession to the European Union, Journal of International Studies, 7(3), 20-31.

Kandakoglu, A., Celik, M. \& Akgun, I. (2009). A multi-methodological approach for shipping registry selection in maritime transportation industry. Mathematical and Computer Modelling, 2009(49), 586-597.

Koisova, E., Grmanova, E. \& Habanik, J. (2018). Regional disparities in financing innovations in small and mediumsized enterprises. Journal of International Studies, 11(3), 124-136.

Kotikova, S. \& Cuhlova, R. (2016). Foreign Presence, Cultural Distance and Technology Gap as Indicators of Globalization in the Czech Republic. In 16th International Scientific Conference Globalization and Its Socio-Economics Consequences. (pp. 337 - 344). Rajecke Teplice, SK: University of Zilina

Kotikova, S. (2017). The Situation of the Regional Labor Markets with the Hypothetical Absence of Foreign Direct Investment. Ad Alta: Journal of Interdisciplinary Research, 7(1), 78 - 82.

Krugman, P. \& Fujita, M. (2004). The new economic geography: Past, present and the future. Papers in Regional Science, 83, 139-164.

Krugman, P. \& Venables, A. (1995). Globalization and the ineguality of nations. The Quarterly Journal of Economics, 1995(110), $857-880$.

Krugman, P. (2011). The new economic geography, now middle-aged. Regional Studies, 45(1), 1-7.

Marshall, A. (1920). Principles of Economics. London: Macmillan.

Massey, D. (2007). In what sense a regional problem? Regional Studies, 2007(41), 49-59.

Maudos, J., Pastor, J. M. \& Serrano, L. (2008). Explaining the US-EU productivity growth gap: Structural change vs. intra-sectoral effect. Economics Letters, 100(2), 311-313.

Milani, A.S., Shanian, A. \& El-Lahham, C. (2008). A decision-based approach for measuring human behavioral resistance to organizational change in strategic planning. Mathematical and Computer Modelling, 2008(48), 17651774. 
Narula, R. \& Marin, A. (2005). FDI spillovers, absorptive capacities and human capital development: Evidence from Argentina. Working Paper No 96. International Labour Office - Geneva, 36.

Narula, R. (2017). Emerging market MNEs as meta-integrators: the importance of internal networks. International Journal of Technology Management, 74(1-4), 214-220.

Opricovic, S. \& Tzeng, G. (2004). Compromise solution by MCDM methods: A comparative analysis of VIKOR and TOPSIS. European Journal of Operational Research, 2004(154), 445-455.

Pavic, Z. \& Novoselac, V. (2013). Notes on TOPSIS Method. International Journal of Research in Engineering and Science, $1(2), 5-12$.

Peng, Y. et al. (2012). A Multicriteria Decision Making Approach for Estimating the Number of Clusters in a Data Set. PLoS One, 7(7), 9 .

Prokop, J. \& Karbowski, A. (2018). R\&D spillovers and cartelization of industries with differentiated products. Journal of International Studies, 11(3), 44-56.

Sanchez-Sellero, M. C. et al. (2014). Organizational characteristics in the labour satisfaction in Spain. Revista de Administração de Empresas, 54(5), 537-547.

Sharma, P. R. (1984). Growth-centers and Regional-development - Aspects of Theory and Policy, Habitat international, 8, 133-150.

Shih, H., Shyur, H. \& Lee, E.S. (2007). An extension of TOPSIS for group decision making. Mathematical and Computer Modelling, 2007(45), 801-813.

Simanová, J. \& Tresl, F. (2011). Vyvoj prumyslove koncentrace a specializace v regionech NUTS3 Ceske republiky v kontextu dynamizace regionalni komparativni vyhody. E + M Ekonomie a Management, 14(1), 38 - 52.

Simionescu, M. (2018). Effects of European economic integration on foreign direct investment: The case of Romania. Economics \& Sociology, 11(4), 96-105.

Simionescu, M. (2018). The impact of Brexit on the UK inwards FDI. Economics, Management and Sustainability, 3(1), 620.

Szent-Ivanyi, B. \& Vigvari, G. (2012). Spillovers from foreign direct investment in Central and Eastern Europe. Society and Economy, 2012(34), 51-72.

Vavrek, R. \& Chovancova, J. (2019). Assessment of economic and environmental energy performance of EU countries using CV-TOPSIS technique. Ecological Indicators, 106, 105519.

Vavrek, R. (2017). Weight of topsis technique parameter and its impact on assessment of municipalities in Slovak Republic. Scientific papers of the University of Pardubice, 24(39), 236-246.

Vavrek, R., Kotulic, R. \& Adamisin, P. (2015). Evaluation of municipalities management with the TOPSIS technique emphasising on the impact of weights of established criteria. Lex localis - Journal of Local Self-Government, 13(2), 249-264.

Vernon, R. (1966). International investment and international trade in the product cycle. Quarterly Journal of Economics, 80(2), 190-207.

Wu, Ch., Hsieh, Ch. \& Chang, K. (2013). A hybrid multiple criteria decision making model for supplier selection. Mathematical Problems in Engineering, 2103, 8.

$\mathrm{Xu}$, B. (2000). Multinational enterprises, technology diffusion, and host country productivity growth. Journal of Development Economics, 62, 477-493.

Zavadskas, E. K., Mardani, A., Turskis, Z., Jusoh, A. \& Nor, K. (2016). Development of TOPSIS method to solve complicated decision-making problems: An overview on developments from 2000 to 2015. International Journal of Information Technology \& Decision Making, 15, WSPC/173-IJITDM.

Zdenek, R. \& Strelecek, F. (2012). Hodnoceni vyvoje zamestnanosti, prumerne mzdy a produktivity prace pomoci shift-share analyzy. E + M Ekonomie a Management, 15(3), 4-15. 